Review Article

\title{
Defense-related proteins involved in sugarcane responses to biotic stress
}

\author{
Thais P. Souza ${ }^{1}$, Renata O. Dias ${ }^{1}$ and Marcio C. Silva-Filho ${ }^{1}$ \\ ${ }^{1}$ Departamento de Genética, Escola Superior de Agricultura Luiz de Queiroz, Universidade de São Paulo, \\ Piracicaba, SP, Brazil.
}

\begin{abstract}
Sugarcane is one of the most important agricultural crops in the world. However, pathogen infection and herbivore attack cause constant losses in yield. Plants respond to pathogen infection by inducing the expression of several protein types, such as glucanases, chitinases, thaumatins, peptidase inhibitors, defensins, catalases and glycoproteins. Proteins induced by pathogenesis are directly or indirectly involved in plant defense, leading to pathogen death or inducing other plant defense responses. Several of these proteins are induced in sugarcane by different pathogens or insects and have antifungal or insecticidal activity. In this review,defense-related proteins in sugarcane are described, with their putative mechanisms of action, pathogen targets and biotechnological perspectives.
\end{abstract}

Keywords: Defense-related protein, PR-protein, biotic stress, Saccharum spp.

Received: March 09, 2016; Accepted: September 27, 2016.

\section{Introduction}

Sugarcane (Saccharum spp. hybrids) is the primary source of sugar and renewable biofuel energy worldwide. With high carbohydrate content, favorable energy input/output ratio and high biomass production capacity, sugarcane is one of the best options to generate biofuel (Hoang et al., 2015). The growing global demand for energy has led to increased interest in the development of new sugarcane cultivars with high productivity for use as bioenergy feedstock (Hoang et al., 2015).

Sugarcane production is constantly challenged by different abiotic and biotic stresses (Long and Hensley, 1972; Azevedo et al., 2011). Biotic stresses include, among others, fungal infection by species such as Colletotrichum falcatum (red rot disease), Sporisorium scitamineum (sugarcane smut), Fusarium spp. and Ceratocystis paradoxa (pineapple disease), bacterial diseases such as red stripe (Acidovorax avenae), leaf scald (Xanthomonas Albileneans) and sugarcane grassy shoot disease (Phytoplasma), virus infection by species such as sugarcane mosaic virus (ScMV) and yellow leaf virus (ScYLV), and insect attack by species such as Diatraea saccharalis (sugarcane stem borer), Eldana saccharina (African sugarcane stalkborer) and Sphenophorus levis (sugarcane weevil).

Plants respond to biotic stress by constitutive or inducible defense mechanisms. Many defense related (DR)

Send correspondence to Marcio C. Silva-Filho. Departamento de Genética, Escola Superior de Agricultura Luiz de Queiroz, Universidade de São Paulo, Av. Pádua Dias, 11, 13400-918 Piracicaba, SP, Brazil. E-mail: mdcsilva@usp.br

${ }^{*}$ The first two authors contributed equally to this work. proteins have been identified in different plants after infection by fungi, oomycetes, bacteria and viruses or attack by insects and nematodes (Van Loon, 1999; Van Loon et al., 2006).

Plant microbe-induced proteins and their homologs are usually collectively called as "pathogenesis-related" (PR) proteins. However, this concept has been revised to include only proteins induced by pathogens and which are mostly not detectable in their absence (Van Loon et al., 2006). In plant defense responses, PRs affect pathogen or herbivore development (Ryan, 1990; Bohlmann and Broekaert, 1994; Broekaert et al., 1995) or stimulate plant defensive barriers (Van Loon et al., 2006).

Other proteins are also involved in plant defense, such as NBS-LRR proteins, which recognize a wide variety of pathogens and insects (Li et al., 2015), glycoproteins (MMMGs and HMMGs), which are produced after pathogen infection and modify some physiological functions of the invader (Legaz et al., 1998), catalases, which are antioxidant enzymes that detoxify reactive oxygen species (ROS) (Sharma et al., 2012) and WRKY proteins, which comprise a large family of transcription factors that recognize the $\mathrm{W}$ box (TTGACC/T) type DNA sequence, which is found in the promoters of many plant defense genes (Rushton et al., 1996).

This review describes defense-related proteins of sugarcane and addresses their putative mechanisms of action, pathogen targets and biotechnological perspectives. 


\section{PR families and their sugarcane homologs}

PR proteins were first reported in a tobacco variety hypersensitive to tobacco mosaic virus (TMV) infection (Van Loon and Van Kammen, 1970). PRs are classified into 17 different families, PR-1 to PR-17, based on their primary structure and biological activity (Van Loon et al., 1994; van Loon et al., 2006). New PR families have been proposed, such as the PR-18, which was first purified from sunflower (Custers et al., 2004) and the PR-19, which was identified in Scots pine (Sooriyaarachchi et al., 2011).

Several sugarcane proteins presenting homology to different PR families were already described. PR proteins in sugarcane are induced by fungi, bacteria, oomycetes, viruses and insects (Table 1). These PR proteins showed antimicrobial or insecticidal activity (Table 1).

\section{PR-1 family}

The most abundant PR in Nicotiana tabacum is in the PR-1 family, with a high level of induction ( 10,000-fold) in response to pathogen infection (Alexander et al., 1993). PR-1 induction increased the tolerance of different plants, such as tomato, tobacco and Arabidopsis, to pathogens, affecting fungal development (Niderman et al, 1995; Segarra et al., 2013). In transgenic tobacco plants that overexpress the PR-1a gene, tolerance to infection by two oomycetes, Peronospora tabacina and Phytophthora parasitica var. nicotianae, was improved (Alexander et al., 1993). Proteins in the PR-1 family from tobacco and tomato have different levels of fungicidal activity and affect the germination of Phytophthora infestans zoospores (Niderman et al., 1995). PR-1 gene expression was increased in Arabidopsis

Table 1 - Defense related proteins identified in sugarcane in response to biotic stress.

\begin{tabular}{|c|c|c|}
\hline Protein type & Targets & References \\
\hline$\beta$-1 3-glucanase (PR-2) & $\begin{array}{l}\text { Fungi: Colletotrichum falcatum and Sporisorium } \\
\text { scitamineum }\end{array}$ & (Prathima et al., 2013; Su et al., 2013) \\
\hline $\begin{array}{l}\text { Chitinases (PR-3, PR-4, PR-8 and } \\
\text { PR-11) }\end{array}$ & $\begin{array}{l}\text { Fungi: Fusarium solani var. caeruleum; Fusarium } \\
\text { verticillioides; Colletotrichum falcatum; Ceratocystis } \\
\text { paradoxa; Gibberella fujikuroi and Sporisorium } \\
\text { scitamineum }\end{array}$ & $\begin{array}{l}\text { (Franco et al., 2014; Medeiros et al., 2012; Que et } \\
\text { al., 2014) }\end{array}$ \\
\hline \multirow[t]{2}{*}{ Thaumatin (PR-5) } & $\begin{array}{l}\text { Fungi: Sporisorium scitamineum and Colletotrichum } \\
\text { falcatum }\end{array}$ & $\begin{array}{l}\text { (Heinze et al., 2001; Rocha et al., 2007; Sundar et } \\
\text { al., 2008; Viswanathan et al., 2005) }\end{array}$ \\
\hline & Insect: Diatraea saccharalis & \\
\hline \multirow[t]{2}{*}{ Proteinase inhibitors (PR-6) } & Fungi: Trichoderma reesei; & (Ribeiro et al., 2008; Soares-Costa et al., 2002) \\
\hline & Insect: Sphenophorus levis & \\
\hline \multirow[t]{2}{*}{ Peroxidase (PR-9) } & $\begin{array}{l}\text { Fungi: Colletotrichum falcatum; Sporisorium } \\
\text { scitamineum and Puccinia melanocephala }\end{array}$ & (Asthir et al., 2009) \\
\hline & Bacteria: Gluconacetobacter diazotrophicus & \\
\hline Ribonuclease-like (PR-10) & $\begin{array}{l}\text { Fungi: Sporisorium scitamineum and Puccinia } \\
\text { melanocephala }\end{array}$ & (Oloriz et al., 2012; Que et al., 2014) \\
\hline Defensin (PR-12) & $\begin{array}{l}\text { Fungi: Aspergillus niger; Fusarium solani and } \\
\text { Neurospora crassa }\end{array}$ & (De-Paula et al., 2008) \\
\hline Lipid-transferprotein (PR-14) & Bacteria: Burkholderia sacchari & (Borrás-Hidalgo et al., 2005) \\
\hline \multirow[t]{2}{*}{ NBS-LRR protein } & $\begin{array}{l}\text { Fungi: Colletotrichum falcatum and Puccinia } \\
\text { melanocephala }\end{array}$ & $\begin{array}{l}\text { (Borrás-Hidalgo et al., 2005; Carmona et al., 2004; } \\
\text { Glynn et al., 2008; Gupta et al., 2010; Rossi et } \\
\text { al., 2003; Selvaraj et al., 2014; Que et al., 2009) }\end{array}$ \\
\hline & Virus: Sugarcane Yellow Leaf Virus (ScYLV) & \\
\hline Glycoproteins & Fungi: Sporisorium scitamineum & $\begin{array}{l}\text { (Fontaniella et al., 2002; Legaz et al., 2011; Martinez } \\
\text { et al., 1990; Millanes et al., 2005; Millanes et } \\
\text { al., 2008) }\end{array}$ \\
\hline \multirow[t]{2}{*}{ Catalases } & $\begin{array}{l}\text { Fungi: Sporisorium scitamineum; Colletotrichum } \\
\text { falcatum and Puccinia melanocephala; }\end{array}$ & $\begin{array}{l}\text { (Asthir et al., 2009; Kuramae et al., 2002; } \\
\text { Lambais, 2001; Lao et al., 2008; Que et al., 2014; } \\
\text { Sundar and Vidhyasekaran, 2003; Su et al., 2014b) }\end{array}$ \\
\hline & $\begin{array}{l}\text { Bacteria: Gluconacetobacter diazotrophicus and } \\
\text { Herbaspirilum rubrisubalbicans }\end{array}$ & \\
\hline WRKY proteins & $\begin{array}{l}\text { Fungi: Puccinia melanocephala; Sporisorium } \\
\text { scitamineum and Colletotrichum falcatum }\end{array}$ & $\begin{array}{l}\text { (Liu et al., 2012; Muthiah et al., 2013; Prathima et } \\
\text { al., 2013; Que et al., 2014; Santos et al., 2015; Sundar } \\
\text { et al., 2012) }\end{array}$ \\
\hline
\end{tabular}


after the inoculation with Botrytis cinerea fungi (Segarra et al., 2013).

For sugarcane, a putative PR-1-encoding gene was observed in the SUCEST database (Sugarcane EST Genome Project) (Kuramae et al., 2002). Based on the increased activity of other members of the PR-1 family, showed in tobacco and tomato, against Phytophthora species (Alexander et al., 1993; Niderman et al., 1995), PR-1 proteins are relevant targets for future studies against the oomycete species that also affect sugarcane.

\section{$\beta$-1,3-glucanases (PR-2 family)}

The PR-2 family includes $\beta$-1,3-glucanases, which are enzymes that catalyze the endo-type hydrolytic cleavage of 1,3- $\beta$-D-glucosidic linkages in $\beta$-1,3-glucans (Leubner-Metzger and Meins Jr, 1999). These enzymes are involved in several physiological and developmental processes in non infected plants (Romero et al., 1998; Leubner-Metzger, 2003; Balasubramanian et al., 2012) and in responses to abiotic (Hincha et al., 1997) and biotic factors (Kemp et al., 1999; Leubner-Metzger and Meins Jr, 1999). $\beta$-1,3-Glucanases release $\beta$-glucans from fungal cell walls, which in turn can act as elicitors in plant defense, inducing accumulation of the antibiotic phytoalexin (Sharp et al., 1984; Okinaka et al., 1995).

In sugarcane, $\beta$-1,3-glucanase genes are differentially expressed after C. falcatum (Prathima et al., 2013) and $S$. scitamineum (Su et al., 2013) infection, with different expression profiles. In response to both $S$. scitamineum infection and abiotic stresses, ScGluAl (KC848050) was upregulated, whereas ScGluD1 (KC848051) was slightly down-regulated ( $\mathrm{Su}$ et al., 2013). The activity was variable for $\beta$-1,3-glucanase in genotypes with different levels of susceptibility to $S$. scitamineum. For example, following infection with $S$. scitamineum, glucanase activity increases more rapidly and last longer in a variety of sugarcane resistant to smut than in a susceptible one (Su et al., 2013).

\section{Chitinases (PR-3, PR-4, PR-8 and PR-11 families)}

Chitinases are enzymes that hydrolyze the $\beta-1,4$-linkage between $N$-acetylglucosamine residues of chitin, which is a structural polysaccharide that is the primary component of cell walls of several types of fungi and exoskeletons of invertebrates (Datta et al., 1999). In the molecular defense of plants, chitinases degrade the chitin in fungal cell walls, with a consequent inhibition of pathogen growth (Schlumbaum et al., 1986). These proteins are grouped in several classes based on sequence similarity and are distributed in four PR families: PR-3, PR-4, PR-8 and PR-11 (Neuhaus, 1999).

Chitinase proteins in sugarcane are associated with responses to biotic and abiotic stresses ( $\mathrm{Su}$ et al., 2014a, 2015).The ScChiVIII gene showed differential expression pattern in sugarcane genotypes resistant and susceptible to smut (Wang et al., 2014). Transcript levels of chitinase genes were differentially expressed after infection by the fungi C. falcatum (Sundar et al., 2008; Rahul et al., 2013), S. scitamineum (Su et al., 2014a, 2015; Que et al., 2014) and Giberella fujikuroi (Lin et al., 2010). Additionally, the constitutive chitinase activity was higher in sugarcane varieties resistant to red rot disease than in susceptible genotypes (Viswanathan, 2012).

The sugarcane chitinase ScChi, an acidic class III chitinase (PR-8 family), has antifungal activity and inhibits the hyphal growth of Fusarium solani var. coeruleum (Que et al., 2014). Moreover, sugarcane chitinases showed action against $C$. falcatum and are also associated with Pseudomonas-mediated induced resistance (Viswanathan et al., 2003) and with sugarcane response to $D$. saccharalis attack (Medeiros et al., 2012).

Sugarcane has two homologs (SUGARWIN1 and SUGARWIN2) of the antifungal barley wound-inducible protein BARWIN, a class II chitinase (PR-4 family) (Medeiros et al., 2012). BARWIN is a basic protein composed of 125 residues, with the tridimensional structure stabilized by three disulfide bonds (Ludvigsen and Poulsen, 1992; Svensson et al., 1992). Proteins with a domain similar to BARWIN are observed in several different plants, with (Broekaert et al., 1990) or without an associated chitinbinding domain (Friedrich et al., 1991; Linthorst et al., 1991; Caruso et al., 1999), including Hevea brasiliensis, Solanum lycopersicum, Nicotiana tabacum and Triticum aestivum. These proteins have antimicrobial activities toward fungi (Hejgaard et al., 1992; Caruso et al., 1999; Zhu et al., 2006) or both fungi and bacteria (Kiba et al., 2003).

Transcript levels of genes encoding SUGARWINs were up-regulated in response to mechanical wounding, sugarcane borer ( $D$. saccharalis) attack and methyl jasmonate treatment (Medeiros et al., 2012). Although induced by $D$. saccharalis damage, SUGARWIN2 proteins have no insecticidal activity; however, these proteins have an antimicrobial role against the opportunistic fungi Fusarium verticillioides (Medeiros et al., 2012) and C. falcatum (Franco et al., 2014), which typically develop after sugarcane borer attacks. Based on these results, SUGARWIN2 proteins are likely involved in a finely regulated defense mechanism in which insect damage induces plant defenses against imminent opportunistic fungi (Medeiros et al., 2012; Franco et al., 2014). Moreover, the sugarcane pathogenic fungus $C$. paradoxa was affected by SUGARWIN2, but the nonpathogenic fungi Aspergillus nidulans and Saccharomyces cerevisiae are not (Franco et al., 2014). With SUGARWIN2, the morphogenesis and viability of the target fungus were affected by increasing vacuolization, points of fractures and overflow of intracellular material, which lead to cell death (Medeiros et al., 2012; Franco et al., 2014). 


\section{Thaumatin-like proteins (PR-5 family)}

Thaumatin-like proteins (TLPs) have a sequence similar to that of thaumatin, a protein extracted from Thaumatococcus daniellii (a west African shrub). Thaumatin is a monomeric protein composed of 207 residues and stabilized by eight disulfide bonds (Kim et al., 1988). TLPs are induced by biotic and abiotic stresses (Velazhahan et al., 1999; Rajam et al., 2007). In in vitro assays, the plasma membranes (PL) of fungi were disrupted by the antifungal activity of TLPs (Vigers et al., 1992).The mechanisms responsible for the fungal plasma membrane rupture are the direct insertion of TLP in its membrane (formation of pores), causing changes in membrane permeability (Roberts and Selitrennikoff, 1990), or by the hydrolysis of $\beta$-1,3-glucans from fungal cell walls (Grenier et al., 1999).

TLP was induced in sugarcane after $S$. scitamineum (smut) inoculation (Heinze et al., 2001), C. falcatum glycoprotein elicitor treatment (Sundar et al., 2008) and in response to $D$. saccharalis attack (Rocha et al., 2007). PR-5 genes were differentially expressed after sugarcane challenge with C. falcatum (Sathyabhama et al., 2015).

\section{Peptidase inhibitors (PR-6 family)}

Peptidase inhibitors (PIs) in plants are important in the control of endogenous and exogenous peptidase activity. The activity of PIs in plant defense is primarily to inhibit the peptidases secreted by insects and pathogenic microorganisms with the digestion of these proteins (Habib and Fazili, 2007).

Plant cystatins, or phytocystatins (PhyCys), are one of the most studied plant protease inhibitors (Benchabane et al., 2010). They are competitive and reversible inhibitors of cysteine proteases (Martínez and Díaz, 2008). The genes of the cystatin family have been identified and characterized in some plant species, demonstrating functions in defense against pathogens (Bobek and Levine, 1992; Gutierrez-Campos et al., 1999; Belenghi et al., 2003), in response to insect attack (Goulet et al., 2008; Konrad et al., 2008; Liang et al., 2015), in programmed cell death (Solomon et al., 1999; Zhao et al., 2013), in seed germination (Hwang et al., 2009, Zhao et al., 2014), and in responses to abiotic environmental stresses (Hwang et al., 2010). Furthermore, the genes in the cystatin family were differentially expressed in response to different abiotic/biotic stresses, with essential roles in plant defense and hypersensitive cell death (Koiwaet al. 2000; Belenghi et al. 2003; van der Linde et al., 2012, Wang et al., 2015).

Canecystatin, a sugarcane phytocystatin, is composed of 106 amino acid residues and typically seems to occur as a domain-swapped dimer in solution (Valadares et al., 2013). The canecystatin dimerization mechanism turns this inhibitor inactive, avoiding the inhibition of nontarget endogenous cysteine peptidases (Valadares et al., 2013).
The Sugarcane Genome Project SUCEST was the first to characterize canecystatin (Soares-Costa et al., 2002). Following recombinant expression and purification, the antifungal activity of canecystatin was demonstrated against Trichoderma reesei by reducing germination of the filamentous fungus (Soares-Costa et al., 2002). The canecystatin provided inhibitory effect against thiol peptidases, showing that may provide protection for sugarcane against fungi and insects (Oliva et al., 2004). Purified from transgenic sugarcane, His-tagged CaneCPI-1 affects the catalytic activity of cysteine peptidases partially purified from the midgut of the coleopteran S. levis (sugarcane weevil; Ribeiro et al., 2008). Furthermore, some sugarcane cystatins present high homology with the mir 1 gene from maize, which inhibits the growth of a wide range of lepidopteran species (Pechan et al., 2000). These results corroborate that cystatins have potential roles in the defense of sugarcane against insect pests.

In addition to the well-described cysteine peptidase inhibitors, sugarcane also has serine peptidase inhibitors of the Bowman-Birk type (BBI) (Mello et al., 2003). BBIs are small double-headed serine peptidase inhibitors that are highly stabilized by several disulfide bonds (Birk, 1985). Sugarcane likely has at least 14 BBI genes, with highly variable compositions of the amino acid sequences (Mello et al., 2003). The introduction of soybean Bowman-Birk and Kunitz-type serine peptidase inhibitors into sugarcane transgenic lines significantly retards the development of $D$. saccharalis, although the damage caused by this herbivore was not prevented (Falco and Silva-Filho, 2003).

\section{Endoproteinases (PR-7 family)}

The proteins in the PR-7 family are similar to potato alkaline endoproteinase $\mathrm{p}-69$, which is the primary PR in tomato involved in the response to citrus exocortis viroid (CEV) infection (Vera and Conejero, 1988), and to the subtilisin serine protease family (Tornero et al., 1997). Endoproteinases are essential in hydrolyzing peptide bonds in the process of protein degradation. The role of these proteins in biotic defense is unclear, but these proteins may contribute to the dissolution of microbial cell walls (van Loon et al., 2006) or to the posttranslational modification of proteins involved in plant defense (Tornero et al., 1996). The genes $P 69 B$ and $P 69 C$ from tomato inserted into transgenic Arabidopsis are induced by salicylic acid and by plant interaction with Pseudomonas syringae (Jordá and Vera, 2000).

Endoproteinase genes with diverse substrate specificity are reported in sugarcane, but their involvement in plant defense remains to be explored (Correa et al., 2001; Ramos and Selistre-de-Araujo, 2001; Santos-Silva et al., 2012).

\section{Peroxidases (PR-9 family)}

Peroxidases are glycoproteins that catalyze the oxidation of several organic and inorganic substrates by $\mathrm{H}_{2} \mathrm{O}_{2}$ 
and are involved in a wide variety of physiological and plant defense processes (Chittoor et al., 1999). Peroxidases respond to biotic stress by affecting cell wall cross-linking and by creating an unfavorable environment for pathogen growth in plants with the generation of reactive oxygen species (ROS) (Passardi et al., 2005). The role of peroxidases in plant cell walls is associated with the biosynthesis of lignin, which is a phenolic biopolymer synthesized for mechanical support and in response to pathogen attack in vascular plants (Østergaard et al., 2000). For example, ATP A2 peroxidase in Arabidopsis thaliana is a lignin-associated peroxidase that was potentially used in defense against pathogens (Østergaard et al., 2000).

In sugarcane, peroxidase activity increases after inoculation with the pathogen C. falcatum (red rot) (Sundar et al., 2006), with a greater increase in activity in a resistant genotype than in a susceptible one (Asthir et al., 2009). Additionally, an elicitor isolated from C. falcatum induces peroxidase activity in sugarcane leaves and in suspensioncultured cells (Sundar et al., 2002). For sugarcane varieties with different levels of susceptibility to $S$. scitamineum, enzyme activity levels were also variable, with higher increases in activity in a resistant genotype than in a susceptible one after inoculation with the pathogen (Esh et al., 2014). Transcripts encoding peroxidase genes were also induced in sugarcane tissues infected by Gluconacetobacter diazotrophicus (Lambais, 2001) and during interaction with Puccinia melanocephala (Carmona et al., 2004).

\section{Ribonuclease-like proteins (PR-10 family)}

The PR-10 family includes intracellular proteins with ribonuclease activity (Van Loon et al., 1994). PR-10 proteins are induced by pathogens in several plants and shown to possess antifungal, antibacterial, antiviral and antinematode activity (Fernandes et al., 2013; Park et al., 2004; McGee et al., 2001).

In sugarcane, PR-10 homologs were induced after treatment with the defense-regulator methyl jasmonate (MJ) (Bower et al., 2005) and inoculation of sugarcane buds with S. scitamineum (Que et al., 2014) and in response to P. melanocephala infection (Oloriz et al. 2012).

\section{Defensins (PR-12 family)}

Plant defensins are small, cysteine-rich antimicrobial peptides found in several organisms, typically with a characteristic $\beta$-fold (Stotz et al., 2009). These cationic peptides, likely act as antimicrobial molecules that induce the formation of pores in pathogen membranes or modify membrane permeability by a mechanism based on electrostatic charge (Thomma et al., 2002).

Sugarcane has at least three putative functional defensins: Sd1, Sd3 and Sd5 (De-Paula et al., 2008). Sd1, $\mathrm{Sd} 3$ and $\mathrm{Sd} 5$ have antifungal activity against the fungi Aspergillus niger, F. solani and Neurospora crassa; however, these proteins have no antibacterial activity against
Kocuria rhizophila, Bacillus subtilis, Escherichia coli and Staphylococcus aureus (De-Paula et al., 2008).

\section{Lipid-transferproteins (PR-14 family)}

Lipid-transfer proteins (LTPs) are small, basic and cysteine-rich lipid-binding proteins in plants that transport lipids between membranes in vitro (Rueckert and Schmidt, 1990). These proteins are observed in plant cell walls, with putative roles in cutin biosynthesis and in response to biotic and abiotic stresses (Kader, 1997). Genes encoding the PR-14 type-member, barley LTP4, are differentially induced after fungal and bacterial inoculation (Molina and García-Olmedo, 1993; Molina et al., 1996).

After pathogen inoculation, putative homologs of LTPs are differentially induced in a sugarcane genotype resistant to eyespot (Biopolaris sacchari; Borrás-Hidalgo et al., 2005).

\section{Other defense-related proteins in sugarcane}

\section{NBS-LRR proteins}

Plant NBS-LRR proteins are used to recognize a wide variety of pathogens and insects (Li et al. 2015). These proteins encoded by plant resistance genes contain two typical domains: a nucleotide binding site (NBS) and a leucinerich repeat (LRR). Plant NBS-LRR proteins detect the effector molecules of pathogens that are responsible for virulence. The NBS-LRR class of R genes is categorized into TIR and non-TIR classes based on sequence similarity in the region that precedes the NBS domain. The plant NBSLRR proteins in the TIR class transport the TOLL/interleukin-1 receptor (TIR) and are called TNL proteins (Joshi and Navak, 2011). The TIR class was found in most dicots but is rare or absent in monocots (Bai et al., 2002; Meyers et al., 2003). The proteins in the non-TIR class are typically called CNL proteins, with most members containing a coiled-coil (CC) N-terminal domain or zinc finger and RPW8 domains (Meyers et al., 2002, DeYoung and Innes, 2006). The CNL class was found in both dicots and monocots (Pan et al., 2000).

Red-rot-related NBS-LRR genes were found in sugarcane EST databases (Gupta et al., 2010); these genes were up-regulated in response to $C$. falcatum challenge, suggesting a possible role in systemic acquired resistance, SAR (Selvaraj et al., 2014). These genes were also induced in sugarcane somaclonal variants during interaction with $P$. melanocephala (Carmona et al., 2004). An NBS-LRR class resistance-gene, non-TIR-NBS-LRR-type, was induced in sugarcane in response to infection by S. scitamineum, the causal agent of smut (Borrás-Hidalgo et al., 2005; Que et al., 2009).

Resistance-associated genes that encode an NBS domain have been identified in plants using disease resistance gene analog (RGA) markers (Sekhwal et al., 2015). RGA sequences are a large set of potential resistance-associated 
genes with conserved domains. The NBS domain was used to amplify RGA fragments from various plant species (Wang et al., 2001). For example, NBS-RGA analogs from wheat and soybean were used to amplify NBS-LRR DNA in sugarcane; the genes identified were associated with resistance against yellow leaf virus (SCYLV) and moderate resistance against rust caused by $P$. melanocephala (Glynn et al., 2008). Non-TIR-NBS-LRR resistance genes (Xal and RPS2) and TIR-NBS-LRR resistance genes ( $L 6$ and $N$ ) were also identified in sequences of RGAs from smutresistant sugarcane (Que et al., 2009). Eighteen other sugarcane NBS-LRR gene homologs were found in the SUCEST database with homology to maize and rice varieties resistant to rust (Rossi et al., 2003). Analyses of these genes may enhance the understanding of stress-responsive pathways in sugarcane and lead to the development of markers for disease.

\section{Glycoproteins}

The production of glycoproteins is likely the primary response of sugarcane to infection by pathogens (Fontaniella et al., 2002). These macromolecules are found in plant cell walls (Martínez et al. 1990) and are of two types, mid molecular mass glycoproteins (MMMGs) or high molecular mass glycoproteins (HMMGs) (Legaz et al., 1998).

In response to the entry of a pathogen, sugarcane glycoproteins (MMMGs and HMMGs) are produced that modify some physiological functions of the invader. These glycoproteins were first isolated from sugarcane juice produced in response to mechanical injuries (Legaz et al., 1998).

The inoculation of sugarcane with smut teliospores of S. scitamineum induces a significant increase in concentration of HMMGs, the polymers from which MMMGs are derived (Martínez et al. 1990). In other studies on smut disease, both types of glycoproteins act against the fungus by increasing cytoagglutination and decreasing the germination of teliospores by $50 \%$ (Fontaniella et al., 2002) or by preventing cell polarization with inhibition of germination tube protrusion and spore germination (Millanes et al., 2005). Furthermore, HMMGs and MMMGs produced by healthy sugarcane cause a complete inhibition of smut mycelium growth (Millanes et al., 2008).

Xanthomonas albilineans is the causal agent of leaf scald, a bacterial-vascular disease in sugarcane. Sugarcane HMMGs and MMMGs act as cell-to-bacterial signals inducing the production of xanthan, an exocellular polysaccharide, by $X$. albilineans. The production of xanthan is likely caused by inhibition of bacterial proteases by these glycoproteins, which consequently protects the enzymes responsible for xanthan biosynthesis from proteolytic degradation (Legaz et al., 2011).

\section{Catalases}

Catalase was the first antioxidant enzyme discovered and characterized. In plants, these enzymes detoxify reactive oxygen species (ROS). Catalases are hemeproteins that have high specificity for $\mathrm{H}_{2} \mathrm{O}_{2}$ and catalyze the dismutation of two molecules of $\mathrm{H}_{2} \mathrm{O}_{2}$ into water and oxygen (Sharma et al., 2012).

A search in the SUCEST database found catalases with similarities to the three maize isoforms (CAT 1, CAT 2 and CAT 3) (Soares Netto, 2001). The level of gene expression for a catalase isoform (CAT3) increases after infection with $G$. diazotrophicus (2.5-fold), Herbaspirillum rubrisubalbicans (5-fold) (Lambais, 2001) and $S$. scitamineum (Lao et al., 2008). CAT 1 and CAT 3 were also found in sugarcane leaves inoculated with the pathogen $P$. melanocephala, the causal agent of sugarcane rust disease (Kuramae et al., 2002).

The elicitor of $C$. falcatum induces variable levels of catalase in suspension-cultured sugarcane cells (Sundar and Vidhyasekaran, 2003). Moreover, high catalase activity was found in two cultivars with varying sensitivity to $C$. falcatum after inoculation with conidia of red rot fungus (Asthir et al., 2009).

After inoculation with $S$. scitamineum, the expression of the catalase gene $(S c C A T 1)$ in sugarcane increases significantly, which suggests that $S c C A T 1$ protects plants against reactive oxidant-related fungal stimuli. Based on this study, a positive correlation between activity of catalase and smut resistance in sugarcane was also confirmed ( $\mathrm{Su}$ et al., 2014b). Furthermore, the transcription and expression of the catalase gene were also induced by this interaction (Que et al., 2014).

\section{WRKY proteins}

WRKY proteins are a large family of transcription factors. These proteins are named because of a highly conserved 60 amino acid-long WRKY domain, which is composed of the highly conserved motif WRKYGQK at the $\mathrm{N}$-terminus and a novel metal-chelating zinc finger signature at the C-terminus (Agarwal et al., 2011). WRKY proteins recognize the $\mathrm{W}$ box (TTGACC/T) type DNA sequence, which was found in the promoters of many plant defense genes (Rushton et al., 1996). WRKY proteins are involved in differential responses to biotic stresses in plants, either as transcriptional activators or as repressors of pathogen-induced defense programs (Eulgem, et al., 2000; Dong et al., 2003; Ulker and Somssich, 2004; JournotCatalino et al., 2006). Plant WRKY transcriptional factors are activated as part of the plant innate immune system and are triggered by pathogen-associated molecular patterns (PAMP-triggered immunity or PTI) and pathogen virulent effectors (effector-triggered immunity or ETI) (Jones and Dangl, 2006). The high percentage of genes in this family compared with that of other multigene families that also encode plant transcription factors suggests that biotic stresses 
may have played a key role in the expansion of the WRKY family (Ulker and Somssich, 2004; Agarwal et al., 2011).

Data analyses of sugarcane defense-related genes from many projects worldwide identified WRKY genes (Lambais, 2001; Liu et al., 2012; Wanderley-Nogueira et al., 2012; Que et al., 2014; Santos et al., 2015). The expression of $\beta$-1,3-glucanases, chitinases, peroxidases and catalases was co-regulated with WRKY-like genes in sugarcane (Dellagi et al., 2000; Hara et al., 2000). Furthermore, specific isoforms of sugarcane WRKY-like transcription factor are associated with PR regulons (Lambais, 2001). The expression analysis of WRKY genes indicates strong inductions after sugarcane interaction with $U$. scitaminea (Liu et al., 2012), C. falcatum (Sundar et al., 2012; Muthiah et al., 2013; Prathima et al., 2013), S. scitamineum (Que et al., 2014) and P. melanocephala (Santos et al., 2015).

\section{Biotechnology potential of defense-related proteins in sugarcane}

Induced systemic resistance (ISR) is one strategy that has been described as a potential weapon to improve sugarcane resistance to biotic stresses. Rhizobacterial strains of Pseudomonas (nonpathogenic bacteria) were associated with increased resistance in sugarcane to C. falcatum by inducing PR proteins in stalk tissues (Viswanathan et al., 2003) and by increasing chitinases with antifungal activity (Viswanathan and Samiyappan, 2001; Viswanathan et al., 2005).

PR proteins from the families PR-13, PR-15, PR-16, PR-17, PR-18 and PR-19, with homologs not yet found in sugarcane, can also be potential targets for RGA markers for enhanced resistance to pathogens. PR-13 (thionins) destroy fungal and bacterial membranes (Bohlmann and Broekaert, 1994) and in barley and Arabidopsis inhibited the growth of the sugarcane phytopathogenic fungi Thielaviopsis paradoxa (Reimann-Philipp et al., 1989) and Fusarium oxysporum (Epple et al., 1997), respectively. Oxalate oxidases (PR-15 family) and oxalate-oxidase-like proteins (PR-16 family) are correlated with the generation of hydrogen peroxide, which produces a toxic environment to the pathogen or stimulates directly or indirectly plant defense responses (Van Loon et al., 2006). Members of the newly described PR-17 family (Nt PRp27 like) were observed in response to Blumeria graminis in barley (Christensen et al., 2002), induced by the synthetic benzo $(1,2,3)$ thiadiazole-7-carbothioic acid S-methyl ester (BTH) in wheat (Görlach et al., 1996) and upon mosaic virus infection in tobacco. PR-18 (fungus- and SA-inducible carbohydrate oxydases) enhanced resistance to infection by bacteria in tobacco transgenic plants (Custers et al., 2004). Recently, a new PR protein with antimicrobial effect was identified in Pinus sylvestris and named PR-19 (Sooriyaarachchi et al., 2011). This protein binds to fungal cell wall glucans altering cell wall structure which leads to morphological distortion of hyphae (Sooriyaarachchi et al., 2011).

Recently, RNA interference also has been used for control of sugarcane diseases. RNAi of endochitinases in the sugarcane endophyte Trichoderma virens 223 was used as a form of biocontrol for C. paradoxa (Romão-Dumaresq et al., 2012). RNAi has been used for development of viral resistant plants (Kim et al., 2013; Ntui et al., 2013). Gene silencing has proven to be effective to obtain multistrain resistant sugarcane plants for mosaic disease (Potyvirus sugarcane mosaic virus - ScMV and/or Sorghum mosaic virus SrMV)(Guo et al., 2015).

Studies have reported that microRNA-guided gene regulation was essential for tolerance to biotic stresses (Gupta et al., 2014). Thiebaut et al. (2012) identified several microRNAs in sugarcane after inoculation with Acidovorax avenae subsp avenae. These new microRNAs have a potential use for genetic engineering of stressresistant plants and can contribute to an improved understanding of regulatory pathways for defense-related proteins.

The development of transgenic plants is another strategy proposed to increase resistance to pathogens. For example, the insertion of single genes encoding PR proteins, such as $\beta$-1,3-glucanase (Sundaresha et al., 2010) or thaumatin-like proteins (Chen et al., 1999; Datta et al., 1999; Velazhahan and Muthukrishnan, 2003; Schestibratov and Dolgov, 2005), in transgenic plants increases host resistance against fungi. Additionally, transgenic plants that express more than one PR-encoding gene have also been considered as a strategy to improve plant resistance to pathogens (Anand et al., 2003; Amian et al., 2011).

\section{Concluding remarks}

Sugarcane is one of the most important commodities worldwide, primarily for sugar and biofuel production. However, despite the significant agronomical relevance, little is known about the role of proteins in sugarcane defense when compared with other plant species. Improving our knowledge of sugarcane defense mechanisms against pathogens is still a great challenge to be achieved.

\section{Acknowledgments}

This work was supported by São Paulo Research Foundation (FAPESP) grant 14/50275-9 for MCSF. This work was also supported by the Conselho Nacional de Desenvolvimento Científico e Tecnológico (CNPq) grant 482737/2012-3 for MCSF and 168124/2014-9 for ROD. TPS was supported by Fundação de Aperfeiçoamento de Pessoal de Nível Superior (CAPES). MCSF is also research fellow of the CNPq. 


\section{References}

Agarwal P, Reddy MP and Chikara J (2011) WRKY: Its structure, evolutionary relationship, DNA-binding selectivity, role in stress tolerance and development of plants. Mol Biol Rep 38:3883-3896.

Alexander D, Goodman RM, Gut-Rella M, Glascock C, Weymann K, Friedrich L, Maddox D, Ahl-Goy P, Luntz T, Ward E, et al. (1993) Increased tolerance to two oomycete pathogens in transgenic tobacco expressing pathogenesisrelated protein 1a. Proc Natl Acad Sci U S A 90:7327-7331.

Amian AA, Papenbrock J, Jacobsen H-J and Hassan F (2011) Enhancing transgenic pea (Pisum sativum L.) resistance against fungal diseases through stacking of two antifungal genes (chitinase and glucanase). GM Crops 2:104-109.

Anand A, Zhou T, Trick HN, Gill BS, Bockus WW and Muthukrishnan S (2003) Greenhouse and field testing of transgenic wheat plants stably expressing genes for thaumatinlike protein, chitinase and glucanase against Fusarium graminearum. J Exp Bot 54:1101-1111.

Asthir B, Preet K, Batta SK and Sharma B (2009) Role of antioxidative enzymes in red rot resistance in sugarcane. Sugar Tech 11:282-287.

Azevedo RA, Carvalho RF, Cia MC and Gratão PL (2011) Sugarcane under pressure: An overview of biochemical and physiological studies of abiotic stress. Trop Plant Biol 4:42-51.

Bai JF, Pennill LA, Ning JC, Lee SW, Ramalingam J, Webb CA, Zhao BY, Sun Q, Nelson JC, Leach JE, et al. (2002) Diversity in nucleotide binding site-leucine-rich repeat genes in cereals. Genome Res 12:1871-1884.

Balasubramanian V, Vashisht D, Cletus J and Sakthivel N (2012) Plant $\beta$-1, 3-glucanases: Their biological functions and transgenic expression against phytopathogenic fungi. Biotechnol Lett 34:1983-1990.

Belenghi B, Acconcia F, Trovato M, Perazzolli M, Bocedi A, Polticelli F, Ascenzi P and Delledonne M (2003) AtCYS1, a cystatin from Arabidopsis thaliana, suppresses hypersensitive cell death. Eur J Biochem 270:2593-2604.

Benchabane M, Schluter U, Vorster J, Goulet MC and Michaud D (2010) Plant cystatins. Biochimie 92:1657-1666.

Birk Y (1985) The Bowman-Birk inhibitor. Trypsin- and chymotrypsin-inhibitor from soybeans. Int J Pept Protein Res 25:113-131.

Bobek LA and Levine MJ (1992) Cystatins-inhibitors of cysteine proteinases. Crit Rev Oral Biol Med 3:307-332.

Bohlmann H and Broekaert W (1994) The role of thionins in plant protection. CRC Crit Rev Plant Sci 13:1-16.

Borrás-Hidalgo O, Thomma BP, Carmona E, Borroto CJ, Pujol M, Arencibia A and Lopez J (2005) Identification of sugarcane genes induced in disease-resistant somaclones upon inoculation with Ustilago scitaminea or Bipolaris sacchari. Plant Physiol Biochem 43:1115-1121.

Bower NI, Casu RE, Maclean DJ, Reverter A, Chapman SC and Manners JM (2005) Transcriptional response of sugarcane roots to methyl jasmonate. Plant Sci 168:761-772.

Broekaert I, Lee HI, Kush A, Chua NH and Raikhel N (1990) Wound-induced accumulation of mRNA containing a hevein sequence in laticifers of rubber tree (Hevea brasiliensis). Proc Natl Acad Sci U S A 87:7633-7637.
Broekaert WF, Terras F, Cammue B and Osborn RW (1995) Plant defensins: Novel antimicrobial peptides as components of the host defense system. Plant Physiol 108:1353.

Carmona E, Vargas D, Borroto C, Lopez J, Fernández A, Arencibia A and Borrás-Hidalgo O (2004) cDNA-AFLP analysis of differential gene expression during the interaction between sugarcane and Puccinia melanocephala. Plant Breeding 123:499-501.

Caruso C, Bertini L, Tucci M, Caporale C, Leonardi L, Saccardo F, Bressan RA, Veronese P and Buonocore V (1999) Isolation and characterisation of wheat cDNA clones encoding PR4 proteins. DNA Seq 10:301-307.

Chen W, Chen P, Liu D, Kynast R, Friebe B, Velazhahan R, Muthukrishnan S and Gill B (1999) Development of wheat scab symptoms is delayed in transgenic wheat plants that constitutively express a rice thaumatin-like protein gene. Theor Appl Genet 99:755-760.

Chittoor JM, Leach JE and White FF (1999) Induction of peroxidase during defense against pathogens. In: Datta SK and Muthukrishnan S (eds) Pathogenesis-Related Proteins in Plants. CRC Press, Boca Raton, pp 171-193.

Christensen AB, Cho BH, Naesby M, Gregersen PL, Brandt J, Madriz-Ordenana K, Collinge DB and Thordal-Christensen H (2002) The molecular characterization of two barley proteins establishes the novel PR-17 family of pathogenesisrelated proteins. Mol Plant Pathol 3:135-144.

Correa GC, Margis-Pinheiro M and Margis R (2001) Identification, classification and expression pattern analysis of sugarcane cysteine proteinases. Genet Mol Biol 24:275-283.

Custers J, Harrison SJ, Sela-Buurlage MB, van Deventer E, Lageweg W, Howe PW, van der Meijs PJ, Ponstein AS, Simons BH, Melchers LS, et al. (2004) Isolation and characterisation of a class of carbohydrate oxidases from higher plants, with a role in active defence. Plant J 39:147-160.

Datta K, Velazhahan R, Oliva N, Ona I, Mew T, Khush G, Muthukrishnan S and Datta S (1999) Over-expression of the cloned rice thaumatin-like protein (PR-5) gene in transgenic rice plants enhances environmental friendly resistance to Rhizoctonia solani causing sheath blight disease. Theor Appl Genet 98:1138-1145.

De-Paula V, Razzera G, Medeiros L, Miyamoto C, Almeida M, Kurtenbach E, Almeida F and Valente A (2008) Evolutionary relationship between defensins in the Poaceae family strengthened by the characterization of new sugarcane defensins. Plant Mol Biol 68:321-335.

Dellagi A, Helibronn J, Avrova AO, Montesano M, Palva ET, Stewart HE, Toth IK, Cooke DE, Lyon GD and Birch PR (2000) A potato gene encoding a WRKY-like transcription factor is induced in interactions with Erwinia carotovora subsp. atroseptica and Phytophthora infestans and is coregulated with class I endochitinase expression. Mol Plant Microbe Interact 13:1092-1101.

DeYoung BJ and Innes RW (2006) Plant NBS-LRR proteins in pathogen sensing and host defense. Nat Immunol 7:1243-1249.

Dong J, Chen C and Chen Z (2003) Expression profiles of the Arabidopsis WRKY gene superfamily during plant defense response. Plant Mol Biol 51:21-37.

Epple P, Apel K and Bohlmann H (1997) Overexpression of an endogenous thionin enhances resistance of Arabidopsis against Fusarium oxysporum. Plant Cell 9:509-520. 
Esh AMH, Guirgis AA, El-Kholi MMA, El-Absawy EA, Nasr MI and Hassanien EH (2014) The activity of pathogenesis related proteins in smut resistant and susceptible sugarcane (GT54-9) mutants induced by gamma radiation. Adv Plants Agric Res 1:1-12.

Eulgem T, Rushton PJ, Robatzek S and Somssich IE (2000) The WRKY superfamily of plant transcription factors. Trends Plant Sci 5:199-206.

Falco MC and Silva-Filho MC (2003) Expression of soybean proteinase inhibitors in transgenic sugarcane plants: Effects on natural defense against Diatraea saccharalis. Plant Physiol Biochem 41:761-766.

Fernandes H, Michalska K, Sikorski M and Jaskolski M (2013) Structural and functional aspects of PR-10 proteins. FEBS J 280:1169-1199.

Fontaniella B, Márquez A, Rodríguez CW, Piñón D, Solas MT, Vicente C and Legaz ME (2002) A role for sugarcane glycoproteins in the resistance of sugarcane to Ustilago scitaminea. Plant Physiol Biochem 40:881-889.

Franco FP, Santiago AC, Henrique-Silva F, de Castro PA, Goldman GH, Moura DS and Silva-Filho MC (2014) The sugarcane defense protein SUGARWIN2 causes cell death in Colletotrichum falcatum but not in non-pathogenic fungi. PloS ONE 9:e91159.

Friedrich L, Moyer M, Ward E and Ryals J (1991) Pathogenesisrelated protein 4 is structurally homologous to the carboxyterminal domains of hevein, Win-1 and Win-2. Mol Gen Genet 230:113-119.

Glynn NC, Comstock JC, Sood SG, Dang PM and Chaparro JX (2008) Isolation of nucleotide binding site-leucine rich repeat and kinase resistance gene analogues from sugarcane (Saccharum spp.). Pest Manag Sci 64:48-56.

Goulet MC, Dallaire C, Vaillancourt LP, Khalf M, Badri AM, Preradov A, Duceppe MO, Goulet C, Cloutier C and Michaud D (2008) Tailoring the specificity of a plant cystatin toward herbivorous insect digestive cysteine proteases by single mutations at positively selected amino acid sites. Plant Physiol 146:1010-1019.

Grenier J, Potvin C, Trudel J and Asselin A (1999) Some thaumatin-like proteins hydrolyse polymeric $\beta$-1, 3-glucans. Plant J 19:473-480.

Guo JL, Gao SW, Lin QL, Wang HB, Que YX and Xu LP (2015) Transgenic sugarcane resistant to Sorghum mosaic virus based on coat protein gene silencing by RNA interference. Biomed Res Int 2015:1-9.

Gupta OP, Sharma P, Gupta RK and Sharma I (2014) Current status on role of miRNAs during plant-fungus interaction. Physiol Mol Plant Pathol 85:1-7.

Gupta V, Raghuvanshi S, Gupta A, Saini N, Gaur A, Khan MS, Gupta RS, Singh J, Duttamajumder SK, Srivastava S, et al. (2010) The water-deficit stress- and red-rot-related genes in sugarcane. Funct Integr Genomics 10:207-214.

Gutierrez-Campos R, Torres-Acosta JA, Saucedo-Arias LJ and Gomez-Lim MA (1999) The use of cysteine proteinase inhibitors to engineer resistance against potyviruses in transgenic tobacco plants. Nat Biotechnol 17:1223-1226.

Görlach J, Volrath S, Knauf-Beiter G, Hengy G, Beckhove U, Kogel K-H, Oostendorp M, Staub T, Ward E and Kessmann H (1996) Benzothiadiazole, a novel class of inducers of systemic acquired resistance, activates gene expression and disease resistance in wheat. Plant Cell 8:629-643.
Habib H and Fazili KM (2007) Plant protease inhibitors: A defense strategy in plants. Biotechnol Mol Biol Rev 2:68-85.

Hara K, Yagi M, Kusano T and Sano H (2000) Rapid systemic accumulation of transcripts encoding a tobacco WRKY transcription factor upon wounding. Mol Gen Genet 263:30-37.

Heinze B, Thokoane L, Williams N, Barnes J and Rutherford R (2001) The smut-sugarcane interaction as a model system for the integration of marker discovery and gene isolation. Proc S Afr Sug Technol Ass Citeseer, pp 88-93.

Hejgaard J, Jacobsen S, Bjorn SE and Kragh KM (1992) Antifungal activity of chitin-binding PR-4 type proteins from barley grain and stressed leaf. FEBS Lett 307:389-392.

Hincha DK, Meins Jr F and Schmitt JM (1997) [beta]-1, 3-Glucanase is cryoprotective in vitro and is accumulated in leaves during cold acclimation. Plant Physiol 114:1077-1083.

Hoang NV, Furtado A, Botha FC, Simmons BA and Henry RJ (2015) Potential for genetic improvement of sugarcane as a source of biomass for biofuels. Front Bioeng Biotechnol $3: 1-15$.

Hwang JE, Hong JK, Je JH, Lee KO, Kim DY, Lee SY and Lim CO (2009) Regulation of seed germination and seedling growth by an Arabidopsis phytocystatin isoform, AtCYS6. Plant Cell Rep 28:1623-1632.

Hwang JE, Hong JK, Lim CJ, Chen H, Je J, Yang KA, Kim DY, Choi YJ, Lee SY and Lim CO (2010) Distinct expression patterns of two Arabidopsis phytocystatin genes, AtCYS1 and AtCYS2, during development and abiotic stresses. Plant Cell Rep 29:905-915.

Jones JDG and Dangl JL (2006) The plant immune system. Nature 444:323-329.

Jordá L and Vera P (2000) Local and systemic induction of two defense-related subtilisin-like protease promoters in transgenic Arabidopsis plants. Luciferin induction of PR gene expression. Plant Physiol 124:1049-1058.

Joshi RK and Nayak S (2011) Functional characterization and signal transduction ability of nucleotide-binding site-leucinerich repeat resistance genes in plants. Genet Mol Res 10:2637-2652.

Journot-Catalino N, Somssich IE, Roby D and Kroj T (2006) The transcription factors WRKY11 and WRKY17 act as negative regulators of basal resistance in Arabidopsis thaliana. Plant Cell 18:3289-3302.

Kader J-C (1997) Lipid-transfer proteins: A puzzling family of plant proteins. Trends Plant Sci 2:66-70.

Kemp G, Botha A-M, Kloppers F and Pretorius Z (1999) Disease development and $\beta-1,3$-glucanase expression following leaf rust infection in resistant and susceptible near-isogenic wheat seedlings. Physiol Mol Plant Pathol 55:45-52.

Kiba A, Saitoh H, Nishihara M, Omiya K and Yamamura S (2003) C-terminal domain of a hevein-like protein from Wasabia japonica has potent antimicrobial activity. Plant Cell Physiol 44:296-303.

Kim HJ, Kim MJ, Pak JH, Jung HW, Choi HK, Lee YH, Baek IY, Ko JM, Jeong SC, Pack IS, et al. (2013) Characterization of SMV resistance of soybean produced by genetic transformation of SMV-CP gene in RNAi. Plant Biotechnol Rep 7:425-433.

Kim S-H, de Vos A and Ogata C (1988) Crystal structures of two intensely sweet proteins. Trends Biochem Sci 13:13-15.

Koiwa H, Shade RE, Zhu-Salzman K, D'Urzo MP, Murdock LL, Bressan RA and Hasegawa PM (2000) A plant defensive 
cystatin (soyacystatin) targets cathepsin L-like digestive cysteine proteinases (DvCALs) in the larval midgut of western corn rootworm (Diabrotica virgifera virgifera). FEBS Lett 471:67-70.

Konrad R, Ferry N, Gatehouse AM and Babendreier D (2008) Potential effects of oilseed rape expressing oryzacystatin-1 (OC-1) and of purified insecticidal proteins on larvae of the solitary bee Osmia bicornis. PLoS ONE 3:e2664.

Kuramae EE, Fenille RC, Rosa VE, Dias DR, Monteiro JP, Gimenes MA, Palmieri DA, Lima MM and Fávaro RD (2002) Mining of sugarcane ESTs involved in the mechanisms against plant pathogen and environmental stress. Summa phytopatológica 4:315-324.

Lambais MR (2001) In silico differential display of defenserelated expressed sequence tags from sugarcane tissues infected with diazotrophic endophytes. Genet Mol Biol 24:103-111.

Lao M, Arencibia AD, Carmona ER, Acevedo R, Rodriguez E, Leon O and Santana I (2008) Differential expression analysis by cDNA-AFLP of Saccharum spp. after inoculation with the host pathogen Sporisorium scitamineum. Plant Cell Rep 27:1103-1111.

Legaz M-E, Blanch M, Piñón D, Santiago R, Fontaniella B, Blanco Y, Solas M-T and Vicente C (2011) Sugarcane glycoproteins may act as signals for the production of xanthan in the plant-associated bacterium Xanthomonas albilineans. Plant Signal Behav 6:1132-1139.

Legaz ME, de Armas R, Pinon D and Vicente C (1998) Relationships between phenolics-conjugated polyamines and sensitivity of sugarcane to smut (Ustilago scitaminea). J Exp Bot 49:1723-1728.

Leubner-Metzger G (2003) Functions and regulation of $\beta-1$, 3-glucanases during seed germination, dormancy release and after-ripening. Seed Sci Res 13:17-34.

Leubner-Metzger G and Meins Jr F (1999) Functions and regulation of plant $\beta$-1,3-glucanes (PR-2). Datta SK and Muthukrishnan S (eds) Pathogenesis-Related Proteins in Plants. CRC Press, Boca Raton, pp 49-76.

Li X, Kapos P and Zhang Y (2015) NLRs in plants. Curr Opin Immunol 32:114-121.

Liang J, Wang Y, Ding G, Li W, Yang G and He N (2015) Biotic stress-induced expression of mulberry cystatins and identification of cystatin exhibiting stability to silkworm gut proteinases. Planta 242:1139-1151.

Lin S, Zhou Y, Chen G, Zhang Y, Zhang Y, Ning W and Pan D (2010) Molecular responses to the fungal pathogen Gibberella fujikuroi in the leaves of chewing cane (Saccharum officinarum L.). Sugar Tech 12:36-46.

Linthorst HJ, Danhash N, Brederode FT, Van Kan JA, De Wit PJ and Bol JF (1991) Tobacco and tomato PR proteins homologous to win and pro-hevein lack the "hevein" domain. Mol Plant Microbe Interact 4:586-592.

Liu J, Que Y, Guo J, Xu L, Wu J and Chen R (2012) Molecular cloning and expression analysis of a WRKY transcription factor in sugarcane. Afr J Biotechnol 11:6434.

Long W and Hensley S (1972) Insect pests of sugar cane. Annu Rev Entomol 17:149-176.

Ludvigsen S and Poulsen FM (1992) Three-dimensional structure in solution of barwin, a protein from barley seed. Biochemistry $31: 8783-8789$.
Martinez M and Diaz I (2008) The origin and evolution of plant cystatins and their target cysteine proteinases indicate a complex functional relationship. BMC Evol Biol 8:198.

Martinez M, Legaz ME, Paneque M, Dearmas R, Pedrosa MM, Medina I, Rodriguez C and Vicente C (1990) The origin of soluble fructans in sugar-cane juice. Int Sugar J 92:155-159.

McGee JD, Hamer JE and Hodges TK (2001) Characterization of a PR-10 pathogenesis-related gene family induced in rice during infection with Magnaporthe grisea. Mol Plant Microbe Interact 14:877-886.

Medeiros AH, Franco FP, Matos JL, de Castro PA, Santos-Silva LK, Henrique-Silva F, Goldman GH, Moura DS and SilvaFilho MC (2012) Sugarwin: A sugarcane insect-induced gene with antipathogenic activity. Mol Plant Microbe Interact 25:613-624.

Mello MO, Tanaka AS and Silva-Filho MC (2003) Molecular evolution of Bowman-Birk type proteinase inhibitors in flowering plants. Mol Phylogenet Evol 27:103-112.

Meyers BC, Morgante M and Michelmore RW (2002) TIR-X and TIR-NBS proteins: Two new families related to disease resistance TIR-NBS-LRR proteins encoded in Arabidopsis and other plant genomes. Plant J 32:77-92.

Meyers BC, Kozik A, Griego A, Kuang HH and Michelmore RW (2003) Genome-wide analysis of NBS-LRR-encoding genes in Arabidopsis. Plant Cell 15:809-834.

Millanes A-M, Fontaniella B, Legaz M-E and Vicente C (2005) Glycoproteins from sugarcane plants regulate cell polarity of Ustilago scitaminea teliospores. J Plant Physiol 162:253-265.

Millanes A-M, Vicente C and Legaz M-E (2008) Sugarcane glycoproteins bind to surface, specific ligands and modify cytoskeleton arrangement of Ustilago scitaminea teliospores. J Plant Interact 3:95-110.

Molina A and García-Olmedo F (1993) Developmental and pathogen-induced expression of three barley genes encoding lipid transfer proteins. Plant J 4:983-991.

Molina A, Diaz I, Carbonero P, García-Olmedo F and Vasil IK (1996) Two cold-inducible genes encoding lipid transfer protein LTP4 from barley show differential responses to bacterial pathogens. Mol Gen Genet 252:162-168.

Muthiah M, Ramadass A, Amalraj RS, Palaniyandi M and Rasappa V (2013) Expression profiling of transcription factors (TFs) in sugarcane X Colletotrichum falcatum interaction. J Plant Biochem Biotechnol 22:286-294.

Neuhaus JM (1999) Plant chitinases (PR-3, PR-4, PR-8, PR-11). In: Datta SK and Muthukrishnan S (eds) PathogenesisRelated Proteins in Plants. CRC Press, Boca Raton, pp 77-105.

Niderman T, Genetet I, Bruyere T, Gees R, Stintzi A, Legrand M, Fritig B and Mosinger E (1995) Pathogenesis-related PR-1 proteins are antifungal. Isolation and characterization of three 14-kilodalton proteins of tomato and of a basic PR-1 of tobacco with inhibitory activity against Phytophthora infestans. Plant Physiol 108:17-27.

Ntui VO, Kynet K, Azadi P, Khan RS, Chin DP, Nakamura I and Mii M (2013) Transgenic accumulation of a defective cucumber mosaic virus (CMV) replicase derived double stranded RNA modulates plant defence against CMV strains $\mathrm{O}$ and $\mathrm{Y}$ in potato. Transgenic Res 22:1191-1205.

Okinaka Y, Mimori K, Takeo K, Kitamura S, Takeuchi Y, Yamaoka N and Yoshikawa M (1995) A structural model 
for the mechanisms of elicitor release from fungal cell walls by plant [beta]-1, 3-endoglucanase. Plant Physiol 109:839845.

Oliva ML, Carmona AK, Andrade SS, Cotrin SS, Soares-Costa A and Henrique-Silva F (2004) Inhibitory selectivity of canecystatin: A recombinant cysteine peptidase inhibitor from sugarcane. Biochem Biophys Res Commun 320:1082-1086.

Oloriz MI, Gil V, Rojas L, Portal O, Izquierdo Y, Jimenez E and Hofte M (2012) Sugarcane genes differentially expressed in response to Puccinia melanocephala infection: Identification and transcript profiling. Plant Cell Rep 31:955-969.

Østergaard L, Teilum K, Mirza O, Mattsson O, Petersen M, Welinder KG, Mundy J, Gajhede M and Henriksen A (2000) Arabidopsis ATP A2 peroxidase. Expression and highresolution structure of a plant peroxidase with implications for lignification. Plant Mol Biol 44:231-243.

Pan QL, Wendel J and Fluhr R (2000) Divergent evolution of plant NBS-LRR resistance gene homologues in dicot and cereal genomes. J Mol Evol 50:203-213.

Park CJ, Kim KJ, Shin R, Park JM, Shin YC and Paek KH (2004) Pathogenesis-related protein 10 isolated from hot pepper functions as a ribonuclease in an antiviral pathway. Plant $\mathbf{J}$ 37:186-198.

Passardi F, Cosio C, Penel C and Dunand C (2005) Peroxidases have more functions than a Swiss army knife. Plant Cell Rep 24:255-265.

Pechan T, Ye L, Chang Y-M, Mitra A, Lin L, Davis FM, Williams WP and Luthe DS (2000) A unique 33-kD cysteine proteinase accumulates in response to larval feeding in maize genotypes resistant to fall armyworm and other Lepidoptera. Plant Cell 12:1031-1040.

Prathima P, Raveendran M, Kumar K, Rahul P, Kumar VG, Viswanathan R, Sundar AR, Malathi P, Sudhakar D and Balasubramaniam P (2013) Differential regulation of defense-related gene expression in response to red rot pathogen Colletotrichum falcatum infection in sugarcane. Appl Biochem Biotechnol 171:488-503.

Que Y, Su Y, Guo J, Wu Q and Xu L (2014) A global view of transcriptome dynamics during Sporisorium scitamineum challenge in sugarcane by RNA-Seq. PLoS ONE 9:e106476.

Que YX, Xu LP, Lin JW and Chen RK (2009) Isolation and characterization of NBS-LRR resistance gene analogs from sugarcane. Acta Agron Sin 35:631-639.

Rahul P, Kumar VG, Sathyabhama M, Viswanathan R, Sundar AR and Malathi P (2013) Characterization and 3D structure prediction of chitinase induced in sugarcane during pathogenesis of Colletotrichum falcatum. J Plant Biochem Biotechnol 24:1-8.

Rajam M, Chandola N, Goud PS, Singh D, Kashyap V, Choudhary M and Sihachakr D (2007) Thaumatin gene confers resistance to fungal pathogens as well as tolerance to abiotic stresses in transgenic tobacco plants. Biol Plant 51:135-141.

Ramos O and Selistre-de-Araujo H (2001) Identification of metalloprotease gene families in sugarcane. Genet Mol Biol 24:285-290.

Reimann-Philipp U, Schrader G, Martinoia E, Barkholt V and Apel K (1989) Intracellular thionins of barley. A second group of leaf thionins closely related to but distinct from cell wall-bound thionins. J Biol Chem 264:8978-8984.

Ribeiro CW, Soares-Costa A, Falco MC, Chabregas SM, Ulian EC, Cotrin SS, Carmona AK, Santana LA, Oliva ML and
Henrique-Silva F (2008) Production of a His-tagged canecystatin in transgenic sugarcane and subsequent purification. Biotechnol Prog 24:1060-1066.

Roberts WK and Selitrennikoff CP (1990) Zeamatin, an antifungal protein from maize with membrane-permeabilizing activity. Microbiology 136:1771-1778.

Rocha FR, Papini-Terzi FS, Nishiyama MY, Vêncio RZ, Vicentini R, Duarte RD, de Rosa VE, Vinagre F, Barsalobres C and Medeiros AH (2007) Signal transduction-related responses to phytohormones and environmental challenges in sugarcane. BMC Genomics 8:71.

Romao-Dumaresq AS, de Araujo WL, Talbot NJ and Thornton CR (2012) RNA interference of endochitinases in the sugarcane endophyte Trichoderma virens 223 reduces its fitness as a biocontrol agent of pineapple disease. PLoS ONE 7:e47888.

Romero GO, Simmons C, Yaneshita M, Doan M, Thomas BR and Rodriguez RL (1998) Characterization of rice endo-betaglucanase genes (Gns2-Gns14) defines a new subgroup within the gene family. Gene 223:311-320.

Rossi M, Araujo PG, Paulet F, Garsmeur O, Dias VM, Chen H, Van Sluys MA and D'Hont A (2003) Genomic distribution and characterization of EST-derived resistance gene analogs (RGAs) in sugarcane. Mol Genet Genomics 269:406-419.

Rueckert DG and Schmidt K (1990) Lipid transfer proteins. Chem Phys Lipids 56:1-20.

Rushton PJ, Torres JT, Parniske M, Wernert P, Hahlbrock K and Somssich IE (1996) Interaction of elicitor-induced DNAbinding proteins with elicitor response elements in the promoters of parsley PR1 genes. EMBO J 15:5690-5700.

Ryan CA (1990) Protease inhibitors in plants: Genes for improving defenses against insects and pathogens. Annu Rev Phytopathol 28:425-449.

Santos FRC, Pinto LR, Carlini-Garcia LA, Gazaffi R, Mancini MC, Goncalves BS, Medeiros CNF, Perecin D, Garcia AAF, Souza AP, et al. (2015) Marker-trait association and epistasis for brown rust resistance in sugarcane. Euphytica 203:533-547.

Santos-Silva LK, Soares-Costa A, Gerald LT, Meneghin SP and Henrique-Silva F (2012) Recombinant expression and biochemical characterization of sugarcane legumain. Plant Physiol Biochem 57:181-192.

Sathyabhama M, Viswanathan R, Malathi P and Sundar AR (2015) Identification of differentially expressed genes in sugarcane during pathogenesis of Colletotrichum falcatum by suppression subtractive hybridization (SSH). Sugar Tech $18: 176-183$

Schestibratov K and Dolgov S (2005) Transgenic strawberry plants expressing a thaumatin II gene demonstrate enhanced resistance to Botrytis cinerea. Sci Hortic 106:177-189.

Schlumbaum A, Mauch F, Vögeli U and Boller T (1986) Plant chitinases are potent inhibitors of fungal growth. Nature 324:365-367.

Segarra G, Santpere G, Elena G and Trillas I (2013) Enhanced Botrytis cinerea resistance of Arabidopsis plants grown in compost may be explained by increased expression of defense-related genes, as revealed by microarray analysis. PLoS ONE 8:e56075.

Sekhwal MK, Li PC, Lam I, Wang XE, Cloutier S and You FM (2015) Disease resistance gene analogs (RGAs) in plants. Int J Mol Sci 16:19248-19290. 
Selvaraj N, Ramadass A, Amalraj RS, Palaniyandi M and Rasappa V (2014) Molecular profiling of systemic acquired resistance (SAR)-responsive transcripts in sugarcane challenged with Colletotrichum falcatum. Appl Biochem Biotechnol 174:2839-2850.

Sharma P, Jha AB, Dubey RS and Pessarakli M (2012) Reactive oxygen species, oxidative damage, and antioxidative defense mechanism in plants under stressful conditions. J Bot 2012:1-26.

Sharp JK, Valent B and Albersheim P (1984) Purification and partial characterization of a beta-glucan fragment that elicits phytoalexin accumulation in soybean. J Biol Chem 259:11312-11320.

Soares Netto LE (2001) Oxidative stress response in sugarcane. Genet Mol Biol 24:93-102.

Soares-Costa A, Beltramini LM, Thiemann $\mathrm{OH}$ and HenriqueSilva F (2002) A sugarcane cystatin: Recombinant expression, purification, and antifungal activity. Biochem Biophys Res Commun 296:1194-1199.

Solomon M, Belenghi B, Delledonne M, Menachem E and Levine A (1999) The involvement of cysteine proteases and protease inhibitor genes in the regulation of programmed cell death in plants. Plant Cell 11:431-444.

Sooriyaarachchi S, Jaber E, Covarrubias AS, Ubhayasekera W, Asiegbu FO and Mowbray SL (2011) Expression and betaglucan binding properties of Scots pine (Pinus sylvestris L.) antimicrobial protein (Sp-AMP). Plant Mol Biol 77:33-45.

Stotz HU, Thomson JG and Wang Y (2009) Plant defensins: Defense, development and application. Plant Signal Behav 4:1010-1012.

Su Y, Xu L, Fu Z, Yang Y, Guo J, Wang S and Que Y (2014a) ScChi, encoding an acidic class III chitinase of sugarcane, confers positive responses to biotic and abiotic stresses in sugarcane. Int J Mol Sci 15:2738-2760.

Su Y, Guo J, Ling H, Chen S, Wang S, Xu L, Allan AC and Que Y (2014b) Isolation of a novel peroxisomal catalase gene from sugarcane, which is responsive to biotic and abiotic stresses. PLoS ONE 9:e84426.

Su Y, Xu L, Wang S, Wang Z, Yang Y, Chen Y and Que Y (2015) Identification, phylogeny, and transcript of chitinase family genes in sugarcane. Sci Rep 5:10708.

Su YC, Xu LP, Xue BT, Wu QB, Guo JL, Wu LG and Que YX (2013) Molecular cloning and characterization of two pathogenesis-related beta-1,3-glucanase genes ScGluA1 and ScGluD1 from sugarcane infected by Sporisorium scitamineum. Plant Cell Rep 32:1503-1519.

Sundar AR, Velazhahan R, Viswanathan R and Vidhyasekaran P (2002) Induction of active oxygen species (AOS), lipoxygenase and lipid peroxidation in suspension-cultured sugarcane cells by a glycoprotein elicitor isolated from Colletotrichum falcatum. J Plant Dis Protect 109:441-451.

Sundar AR and Vidhyasekaran P (2003) Differential induction of phenylpropanoid metabolites in suspension-cultured cells of sugarcane by fungal elicitors. Acta Phytopathol Entomol Hung 38:29-42.

Sundar AR, Viswanathan R, Malathi P and Padmanaban P (2006) Mechanism of resistance induced by plant activators against Colletotrichum falcatum in sugarcane. Arch Phytopathol Plant Protect 39:259-272.

Sundar AR, Velazhahan R, Nagarathinam S and Vidhyasekaran P (2008) Induction of pathogenesis-related proteins in sugar- cane leaves and cell-cultures by a glycoprotein elicitor isolated from Colletotrichum falcatum. Biol Plant 52:321-328.

Sundar AR, Selvaraj N, Muthiah M, Ramadass A, Malathi P and Viswanathan R (2012) Induced resistance-a potential supplementary strategy for the management of red rot in sugarcane. Funct Plant Sci Biotechnol 6:63-72.

Sundaresha S, Kumar AM, Rohini S, Math S, Keshamma E, Chandrashekar S and Udayakumar M (2010) Enhanced protection against two major fungal pathogens of groundnut, Cercospora arachidicola and Aspergillus flavus in transgenic groundnut over-expressing a tobacco $\beta$ 1-3 glucanase. Eur J Plant Pathol 126:497-508.

Svensson B, Svendsen I, Hoejrup P, Roepstorff P, Ludvigsen S and Poulsen FM (1992) Primary structure of barwin: A barley seed protein closely related to the C-terminal domain of proteins encoded by wound-induced plant genes. Biochemistry $31: 8767-8770$.

Thiebaut F, Grativol C, Carnavale-Bottino M, Rojas CA, Tanurdzic M, Farinelli L, Martienssen RA, Hemerly AS and Ferreira PCG (2012) Computational identification and analysis of novel sugarcane microRNAs. BMC Genomics 13:290.

Thomma BP, Cammue BP and Thevissen K (2002) Plant defensins. Planta 216:193-202.

Tornero P, Conejero V and Vera P (1996) Primary structure and expression of a pathogen-induced protease (PR-P69) in tomato plants: Similarity of functional domains to subtilisinlike endoproteases. Proc Natl Acad Sci U S A 93:63326337.

Tornero P, Conejero V and Vera P (1997) Identification of a new pathogen-induced member of the subtilisin-like processing protease family from plants. J Biol Chem 272:14412-14419.

Ulker B and Somssich IE (2004) WRKY transcription factors: From DNA binding towards biological function. Curr Opin Plant Biol 7:491-498.

Valadares NF, de Oliveira-Silva R, Cavini IA, Marques I de A, Pereira HD, Soares-Costa A, Henrique-Silva F, Kalbitzer HR, Munte CE and Garratt RC (2013) X-ray crystallography and NMR studies of domain-swapped canecystatin-1. FEBS J 280:1028-1038

van der Linde K, Hemetsberger C, Kastner C, Kaschani F, van der Hoorn RA, Kumlehn J and Doehlemann G (2012) A maize cystatin suppresses host immunity by inhibiting apoplastic cysteine proteases. Plant Cell 24:1285-1300.

Van Loon LC (1999) Occurrence and properties of plant pathogenesis-related proteins. In: Datta SK and Muthukrishnan S (eds) Pathogenesis-Related Proteins in Plants. CRC Press LLC, Boca Raton, pp 1-19.

Van Loon L and Van Kammen A (1970) Polyacrylamide disc electrophoresis of the soluble leaf proteins from Nicotiana tabacum var. 'Samsun'and 'Samsun NN': II. Changes in protein constitution after infection with tobacco mosaic virus. Virology 40:199-211.

Van Loon L, Pierpoint W, Boller T and Conejero V (1994) Recommendations for naming plant pathogenesis-related proteins. Plant Mol Biol Report 12:245-264.

Van Loon LC, Rep M and Pieterse CM (2006) Significance of inducible defense-related proteins in infected plants. Annu Rev Phytopathol 44:135-162.

Velazhahan R and Muthukrishnan S (2003) Transgenic tobacco plants constitutively overexpressing a rice thaumatin-like 
protein (PR-5) show enhanced resistance to Alternaria alternata. Biol Plant 47:347-354.

Velazhahan R, Datta SK and Muthukrishnan S (1999) The PR-5 family: Thaumatin-like proteins. In: Datta SK and Muthukrishnan S (eds) Pathogenesis-Related Proteins in Plants. CRC Press LLC, Boca Raton, pp 107-129.

Vera P and Conejero V (1988) Pathogenesis-related proteins of tomato: p-69 as an alkaline endoproteinase. Plant Physiol $87: 58-63$

Vigers AJ, Wiedemann S, Roberts WK, Legrand M, Selitrennikoff CP and Fritig B (1992) Thaumatin-like pathogenesis-related proteins are antifungal. Plant Sci 83:155-161.

Viswanathan R (2012) Molecular basis of red rot resistance in sugarcane. Funct Plant Sci Biotechnol 6:40-50.

Viswanathan R and Samiyappan R (2001) Role of chitinases in Pseudomonas spp. induced systemic resistance against Colletotrichum falcatum in sugarcane. Indian Phytopathol 54:418-423.

Viswanathan R, Nandakumar R and Samiyappan R (2003) Role of pathogenesis-related proteins in rhizobacteria-mediated induced systemic resistance against Colletotrichum falcatum in sugarcane. J Plant Dis Protect 110:524-534.

Viswanathan R, Malathi P, Sundar AR, Aarthi S, Premkumari S and Padmanaban P (2005) Differential induction of chitinases and thaumatin-like proteins in sugarcane in response to infection by Colletotrichum falcatum causing red rot disease. J Plant Dis Protect112:417-425.

Wanderley-Nogueira AC, Kido EA, Soares-Cavalcanti NDMBL and Bezerra-Neto J (2012) Insight on pathogen defense mechanisms in the sugarcane transcriptome. Funct Plant Sci Biotechnol 6:134-148.

Wang SS, Su YC, Yang YT, Guo JL and Xu LP (2014) Molecular cloning and expression analysis of chitinase gene ScChiVII1 in sugarcane. Chin J Trop Crop 35:289-298.

Wang W, Zhao P, Zhou XM, Xiong HX and Sun MX (2015) Genome-wide identification and characterization of cystatin family genes in rice (Oryza sativa L.). Plant Cell Rep 34:1579-1592.

Wang Z, Taramino G, Yang D, Liu G, Tingey SV, Miao GH and Wang GL (2001) Rice ESTs with disease-resistance geneor defense-response gene-like sequences mapped to regions containing major resistance genes or QTLs. Mol Genet Genomics 265:302-310.

Zhao P, Zhou XM, Zhang LY, Wang W, Ma LG, Yang LB, Peng XB, Bozhkov PV and Sun MX (2013) A bipartite molecular module controls cell death activation in the Basal cell lineage of plant embryos. PLoS Biol 11:e1001655.

Zhao P, Zhou XM, Zou J, Wang W, Wang L, Peng XB and Sun MX (2014) Comprehensive analysis of cystatin family genes suggests their putative functions in sexual reproduction, embryogenesis, and seed formation. J Exp Bot 65:5093-5107.

Zhu T, Song F and Zheng Z (2006) Molecular characterization of the rice pathogenesis-related protein, OsPR-4b, and its antifungal activity against Rhizoctonia solani. J Phytopathol 154 378-384.

Associate Editor: Nelson Saibo

License information: This is an open-access article distributed under the terms of the Creative Commons Attribution License (type CC-BY), which permits unrestricted use, distribution and reproduction in any medium, provided the original article is properly cited. 